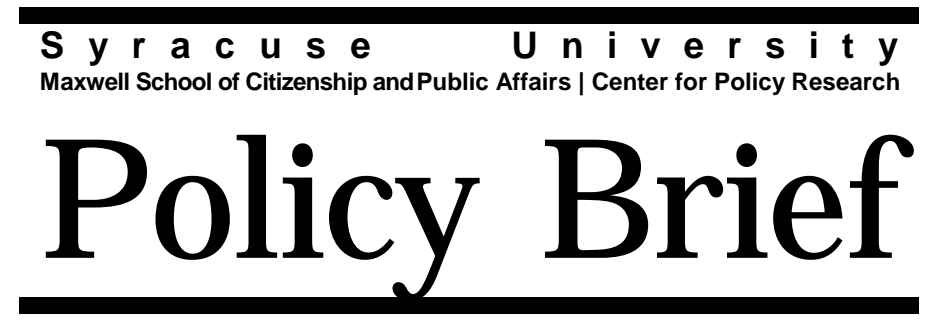

Distinguished LeCturer IN Aging SeRies

The Changing Economic

Circumstances of the Elderly:

Income, Wealth, and Social

Security

James P. Smith

No. 8/1997 


\section{The Changing Economic Circumstances of the Elderly: Income, Wealth, and Social Security}

James P. Smith

How is the economic status of the elderly changing and what are their prospects for the future? My portrait tells us how well off they are on average, but also about the vast disparities that exist among them. This description includes an often neglected measure of their economic well being - the amount of wealth they control. Amazingly little is known about how much personal wealth older people have and how and what determines its distribution. But the conventional definition of household wealth ignores two critical components of wealth: the expected income flows from pensions and Social Security. For some elderly households, Social Security represents the largest part of their wealth. I conclude with some thoughts on one of the most sensitive and critical public policy issues - the necessity of reforming Social Security.

\section{The Changing Economic Status of the Elderly}

This is one of the success stories of American public policy, and we should not be reluctant to tell it. Over the last three decades, the economic position of older Americans has improved dramatically and did so more rapidly than for any other age group.

To illustrate this good news, Figure 1 provides poverty rates for the elderly population alongside the poverty rate for all Americans. In addition, it plots poverty rate for those at the other end of the life cycle-America's children. When John Kennedy was elected President in 1960, more than one in every three older Americans was poor. 


\section{Aging Studies Program Policy Brief}

Today, only one in every eight older people is below the official poverty line. Since the 1960s, poverty has declined twice as fast among the elderly as it has for all Americans. When we started talking about the war on poverty, the image that first entered our minds was of an older person. Today it is a child. Even if we take 1970 as our starting point, poverty among the elderly has been cut in half, while that of children

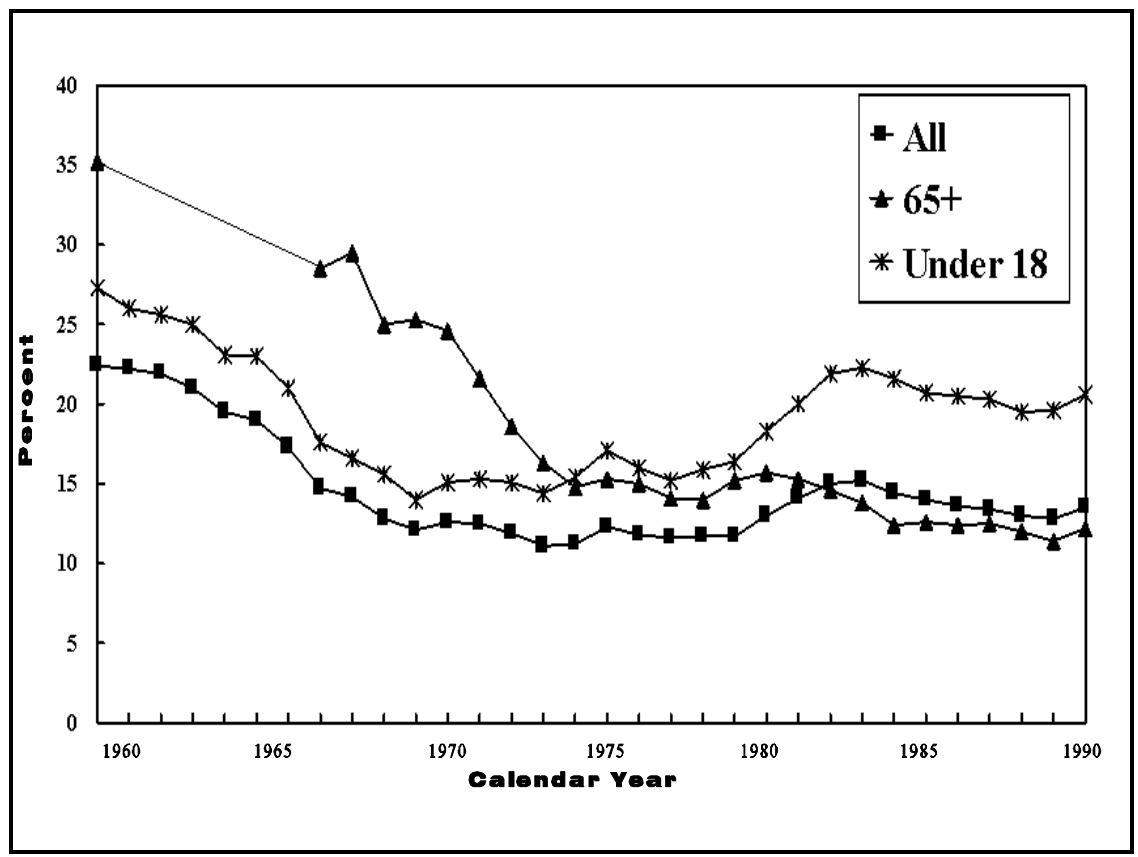

Figure 1. United States Poverty Rates by Age, 1960-1990. Source: U.S. Census Bureau, Current Population Reports, Series P-60, No. 175 (1991), Tables 2 and 3.

has risen by a third.

Figure 1 understates the good news, because the real poverty rate of the elderly is certainly much lower. If we exclude taxes paid, but add in the value of non-cash benefits that the poor receive (food stamps, Medicaid, Medicare), the poverty rate of those aged 65-74 falls by another 2.5 percentage points. If we also include the implicit rental value of housing, only one in every twenty of the elderly is poor today. Such adjustments are appropriate, as they more accurately measure the 
real economic welfare of the elderly. Thus, instead of one in every ten older persons being in poverty (as official statistics would suggest), only one in twenty of the elderly is poor when poverty is better measured.

Such good news should not obscure the equal reality that many older people remain economically vulnerable. This vulnerability is often triggered by certain demographic transitions, particularly a decline into extreme poor health or the death of a spouse. For example, consider the most susceptible population-single elderly women. Using official statistics, one in every four non-married older women is poor, more than twice the rate for all older people. Among elderly widows, poverty rates now run as high as 40 percent. The prospects for older black single women are particularly bleak; seven in every ten of them live below the poverty line. Treating the elderly as a single homogeneous group has lost whatever meaning it may have had either analytically or politically.

\section{Income Levels and Inequality}

This section puts forth some salient facts about the level and distribution of income of American households during their retirement years. It relies on data obtained from the Asset and Health Dynamics among the Oldest Old (AHEAD) study, a critically important new survey funded by the National Institute of Aging (NIA). AHEAD includes 6,052 households (8,204 individuals) with at least one person aged 70 and over in 1994. Its principal purpose is to elucidate the relationship between changes in physical and cognitive health in old age and asset decline. In this survey, blacks, hispanics, and residents of the state of Florida were oversampled at a rate of two to one, and follow-ups are planned every two years. An important advantage of AHEAD is that it contains high quality income and wealth modules 
Aging Studies Program Policy Brief

(Smith 1997). In particular, a very comprehensive and detailed set of questions were asked to measure household wealth. ${ }^{1}$

\begin{tabular}{|c|c|c|}
\hline \multicolumn{3}{|c|}{ Table 1 Mean and Median Household Incomes among the } \\
\hline \multicolumn{3}{|c|}{ Median } \\
\hline All Families & $\$ 15,624$ & Mean \\
\hline Race & & $\$ 23,769$ \\
\hline White & 17,385 & 25,803 \\
\hline Black & 9,467 & 13,250 \\
\hline Hispanic & 8,943 & 12,922 \\
\hline Married & 24,814 & 36,500 \\
\hline Female Headed & 10,613 & 13,960 \\
\hline Age Groups & & 27,753 \\
\hline $70-74$ & 19,461 & 24,002 \\
\hline $75-80$ & 15,357 & 19,359 \\
\hline $81-85$ & 12,335 & 13,834 \\
\hline $86+$ & 9,439 & \\
\hline Source: & Asset and Health Dynamics among the Oldest Old \\
\hline (AHEAD), calculations by author. & \\
\hline
\end{tabular}

${ }^{1}$ In addition to housing equity, assets were separated into the following eleven categories: other real estate; vehicles; business equity; IRA or Keogh; stocks or mutual funds; checking savings or money market funds; CDs, government savings bonds or treasury bills; other bonds; other assets; and other debt. 
Table 1 lists mean and median household incomes stratified by age groups, race, and marital status. There are many important patterns illustrated in this table. First, there exist wide disparities across racial and ethnic groups. For example, the mean income of older black households is about 51 percent as that of white households, and that of older hispanic households is slightly less. But marital status is an even sharper economic discriminator than race or ethnicity. A principal risk faced by older households is the loss of a spouse through divorce, separation, or more commonly death. Men typically die first, often leaving their wives with few economic resources. This harsh reality is reflected in the income figures among female headed families, whose mean income lags that of married families by almost two-thirds.

Finally, there are large disparities across age groups, with the oldest households always faring the worst. In part, this age gradient reflects the increasing frequency of widowhood in older households. But it also results from a significant across-cohort improvement in economic wellbeing so that, even among the currently retired, younger age groups enjoy higher lifetime incomes than their older counterparts.

There is an enormous amount of inequality among older people, far more than exists between them and the rest of the American population. The extent of inequality is best displayed by ignoring minority households completely and examining only older white households. Many older American households are doing quite well indeed. One in every ten of them receives more than $\$ 40,000$ a year, almost three times the income of the median older household. These well-off households can be contrasted with those at the bottom, whose situation can still be quite stark. White elderly households in the lowest 10 percent receive only 43 percent as much as the median white elderly household. Among those over age 70, household incomes of those in the top 5 percent are nine times larger than those in the bottom 10 percent. Although their incomes are lower at every percentile, similar levels of inequality exist among minority households. If anything, the degree of inequality is even larger among these households, where the gap between those at the top and those at the bottom is greater. 


\section{Aging Studies Program Policy Brief}

\section{Sources of Income}

Most Americans receive their income largely from work. Not so for older people whose working days are long behind them. Instead, their incomes are largely formula driven, and often decided on political grounds. In addition, older households differ a great deal in the source of their incomes, a variation that depends critically on where they are in the economic hierarchy.

In the American system, there are 5 principal types of income among retired households:

\# income from work,

\# two annuities: private pensions and Social Security,

\# a set of income conditioned government transfer programs, and

\# income that represents an economic return on the household's accumulated assets.

Figure 2 illustrates the fraction of total household income derived from each of these five sources. The dominant role of Social Security is readily apparent. The median household over age 70 receives about two-thirds of its income from this program. Among less well-to-do households Social Security accounts for more than 80 percent of income. Even for the median black, hispanic or female-headed household, Social Security contributes more than three-quarters of income. 


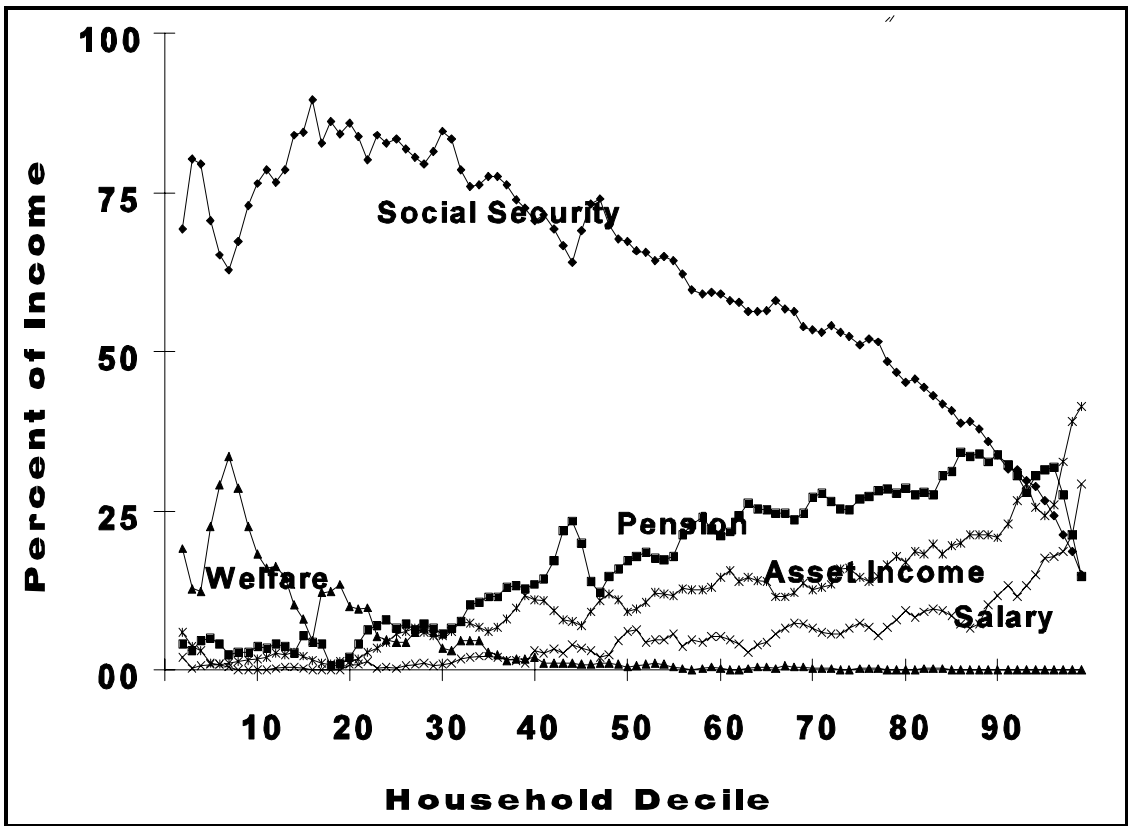

Figure 2. Household Shares of Five Income Sources by Income Decile, Head Aged 70+. Source: AHEAD, calculations by author.

The other annuity in the retirement package-private pensions-has the opposite distributional pattern, being far more important within the top economic strata. Private pensions account for about one-fifth of household income for the median older household; they comprise about one-third of total income of those at the top. But pensions are of little consequence for the bottom third of households, or for the typical older minority household.

During retirement, then, most people rely almost exclusively on a combination of Social Security and private pensions. These two annuities account for about 85 percent of all income for the median older household.

The other three income sources are important only for those households at the economic extremes. Households below the median largely do not work and also derive scant income from any limited assets they might own. These low-income households receive a modest fraction of their 


\section{Aging Studies Program Policy Brief}

incomes from income-conditioned government transfers, but even those in the bottom decile obtain only one dollar of every six from this source. In contrast, roughly a quarter of all income of the top tier of households is obtained as an income flow from their considerable financial assets. Among those in the top 10 percent, this income flow from assets averages over $\$ 10,000$ per year.

\section{Wealth Levels and Inequality}

While income remains their basic economic resource, household wealth is an important complementary measure of their command over economic resources for the elderly. While we know a good deal about income differences, until recently precious little was known about how much personal wealth older people have access to, and how and why that wealth gets distributed. To describe the wealth position of the elderly, I will first use a conventional but comprehensive definition of household wealth. ${ }^{2}$

\# Household wealth includes any equity held in all homes, the value of business and other tangible assets, and a very detailed list of financial assets. These financial assets span checking and savings accounts, stocks and bonds, CDs, IRAs and Keoghs.

Table 2 displays household wealth levels at selected deciles of the full wealth distribution for the AHEAD sample. To provide some contrast with pre-retirement period, Table 2 provides parallel data for households with a member between the ages of 51 and 61 years old in 1992, based on the Health and Retirement Survey (HRS), precursor of AHEAD. Mean household wealth is almost $\$ 270,000$ for those in their 50 s while households over 70 years old have about $\$ 178,000$. These lower asset levels of the retired population may reflect some asset depletion at older ages. However, it mostly results from the fact that these older populations were born twenty years or more before the pre-

${ }^{2}$ This section is based on Smith $(1995,1997)$. 
retirement population and therefore were members of much less prosperous cohorts.

\begin{tabular}{|c|c|c|c|c|}
\hline \multirow{3}{*}{$\begin{array}{l}\text { Table } 2 \\
\\
\text { Deciles }\end{array}$} & \multicolumn{4}{|c|}{ Wealth by Deciles (in 1996 dollars) } \\
\hline & \multicolumn{2}{|c|}{ Ages 70+ (AHEAD) } & \multicolumn{2}{|c|}{ Ages 51-61 (HRS) } \\
\hline & Total & Financial & Total & Financial \\
\hline 10 & $\$ 162$ & $\$ 0$ & $\$ 1,115$ & $\$-1,338$ \\
\hline 30 & 30,311 & 541 & 45,705 & 1,115 \\
\hline 50 & 84,206 & 8,659 & 111,809 & 15,607 \\
\hline 70 & 166,682 & 41,995 & 222,950 & 55,738 \\
\hline 90 & 415,622 & 175,341 & 585,690 & 208,459 \\
\hline 95 & 669,974 & 313,882 & 964,259 & 367,868 \\
\hline Mean & $\$ 177,678$ & $\$ 65,116$ & $\$ 269,946$ & $\$ 81,779$ \\
\hline Source: & \multicolumn{4}{|c|}{$\begin{array}{l}\text { Asset and Health Dynamics among the Oldest Old } \\
\text { (AHEAD) and Health and Retirement Study (HRS), } \\
\text { calculations by author. }\end{array}$} \\
\hline
\end{tabular}

The principal message from Table 2 lies in the extreme diversity in wealth holdings for older populations. Among those aged 70 or over, households in the top 5 percent have $\$ 670,000$ in wealth, about eight times that of the average household. In contrast those retired households in the bottom 10 percent had only a few hundred dollars in household wealth, a small fraction of the average household. Due to this extreme diversity in wealth holdings, wealth among older populations is significantly overstated by the use of means. For example, in contrast to a mean wealth of $\$ 178,000$, the average or median older household (the 50th percentile) has only $\$ 84,000$ in wealth. Similar evidence of extreme diversity in wealth holdings also characterizes pre-retirement households aged in their 50s. 


\section{Aging Studies Program Policy Brief}

A similar story of relatively modest holdings for the average household alongside widespread heterogeneity across households is even more pronounced when financial assets are examined.

\# Financial assets are defined as total wealth minus housing and other real property assets. Financial assets are more liquid and may thus be a better index of a household's ability to deal with emergencies.

Given that criterion, the typical older household has very few resources indeed. The average (median) household over age 70 has less than $\$ 9,000$ in financial assets - only enough to get by for half a year. Once again there exists considerable diversity among these households. For example, among households 70 or over, those in the bottom 10 percent have no financial assets at all while those in the top 5 percent have more than $\$ 300,000$.

These large disparities in wealth holdings among older households translate into correspondingly large disparities when households are stratified by their race or ethnicity. Table 3 lists mean and median levels of total and financial household wealth for white, black, and hispanic households. Race and ethnic disparities are enormous, far outdistancing the income differences within these groups. For example, for every dollar of wealth an older white household has, black households have 25 cents and hispanic households 32 cents on the dollar. These wealth gaps compare to mean racial and ethnic income ratios of about 50 percent among those aged 70 and above.

These racial and ethnic disparities are even larger when we concentrate on financial assets only. Neither the average black nor the average hispanic older household has any financial assets at all. Even the bottom third of white older families have less than $\$ 2,000$ in liquid assets at their disposal. Among those at least 70 years old, for example, black households have only 8 percent of the financial assets of white households. Things are little different if we look at those in their preretirement years. The average black or hispanic household has no financial assets at all. 


\begin{tabular}{|c|c|c|c|c|}
\hline & \multicolumn{2}{|c|}{ Total } & \multicolumn{2}{|c|}{ Financial } \\
\hline & Mean & Median & Mean & Median \\
\hline \multicolumn{5}{|c|}{ Ages 70+ (AHEAD) } \\
\hline White & $\$ 201,336$ & $\$ 102,823$ & $\$ 76,286$ & $\$ 15,586$ \\
\hline Black & 50,143 & 18,957 & 5,877 & 0 \\
\hline Hispanic & 64,091 & 15,586 & 9,126 & 0 \\
\hline \multicolumn{5}{|c|}{ Ages 51-61 (HRS) } \\
\hline White & $\$ 310,765$ & $\$ 138,786$ & $\$ 72,571$ & $\$ 23,410$ \\
\hline Black & 81,219 & 27,869 & 12,780 & 0 \\
\hline Hispanic & 88,821 & 30,464 & 10,585 & 0 \\
\hline Source: & \multicolumn{4}{|c|}{$\begin{array}{l}\text { Asset and Health Dynamics among the Oldest Old } \\
\text { (AHEAD) and Health and Retirement Study (HRS), } \\
\text { calculations by author. }\end{array}$} \\
\hline
\end{tabular}

\# These then are the basic facts about wealth among older American households: modest wealth holdings by the typical older household, large inequities in wealth, and very little evidence of any prior savings behavior by poor or even middle class households.

\section{Why Does the Typical Older Household}

\section{Have So Little Wealth?}

One reason is that those with less income simply have less income to devote to savings. Income does a pretty good job (though far from perfect) of explaining wealth disparities of those at the top, but income alone explains much less of the absence of savings among those below 


\section{Aging Studies Program Policy Brief}

the median. For example, household wealth of whites in the top 5 percent are seven times that of the median white household. After controlling for all income differences, those in the top 5 percent have 1.8 times the wealth of the average household. In contrast, among those at the 20th percentile, households save one-seventh of the median household. Even after adjusting for their income differences, these households at the bottom save only one-fourth the amount of the average family.

The empirical evidence suggests that income explains a significant part, but certainly not all of wealth disparities that exist. The rest flows from much lower savings rate for low- and middle-income households compared to those with higher incomes.

Now why may this be so? One possibility that can easily be dismissed is that these wealth disparities are simply a consequence of wealth being transmitted across generations, with the poor unable to give and the well-to-do insuring that their heirs remain at the top through financial inheritances. The vast majority of households have not received any financial inheritances. For example, two-thirds of all white households and 90 percent of all minority households had received no financial inheritances by their mid-50s. Consequently, inequities in wealth would be about the same if we subtracted out that part of current wealth that flows from past financial inheritances.

It is my belief that there are two principal reasons for this extreme heterogeneity in wealth holdings:

\# different ex-post rates of return to savings across households; and

\# different patterns of savings across households.

The argument that there are different ex-post rates of return does not assert that some households are consistently better investors than other households year after year. This would be a strong assumption for which I know of very little solid evidence. Rather, it states that 
variations in rates of return, even if these returns are uncorrelated over time, will produce heterogeneity in wealth holdings over time.

This argument can best be illustrated with an example. Suppose that all households start out with exactly the same wealth $-\$ 50,000$. In the next year, half the households (randomly chosen) have their wealth increase by 50 percent while the other half have their wealth cut in half. In the second year, we now have diversity where there was none-half the households have $\$ 75,000$ and the other half have $\$ 25,000$. However, mean wealth in the second year is the same as the first $-\$ 50,000$. Now let the process repeat itself with half the households gaining $\$ 25,000$ and half the households losing $\$ 25,000$. Assume further that whether they lose or gain in the third year is unrelated to whether they lost or gained in the second year. At the end of the third year, there are 25 percent of households with $\$ 100,000$, half the households with $\$ 50,000$, and the remaining quarter with no assets at all. This process then continues year after year, spreading out the distribution of wealth even though all households started out with the same amount and had the same prospects of success.

Obviously some individuals may be better investors and can consistently earn high rates of return. Microsoft chairman Bill Gates may be the best current example of wealth produced by high rates of return on investments. His wealth, measured in the billions of dollars, is not the consequence of his prudent savings behavior.

The second, and perhaps even more important reason, lies in different savings behavior across households.

Why do households, even with the same income, save such different amounts from their income? This question is on the frontier of current research, and a full consensus on what the reasons are and which ones rank highest in importance has not been reached. Risk aversion, rates of time preference, and liquidity constraints have all been prominently mentioned (see Deaton 1992). A particularly promising recent explanation is the disincentives to private savings provided by social 


\section{Aging Studies Program Policy Brief}

insurance programs, especially those with asset limits for program eligibility (see Hubbard, Skinner, and Zeldes 1995).

Here, however, I sketch out three other possibilities—-health, bequests and Social Security.

\section{Socio-Economic Status (SES) and Health Status}

A key risk to successful aging rests in a complex two-way interaction between economic status and good health. However, debates about the direction of causation have made conclusions about the relation of health and wealth or income of older populations difficult to pin down. We know that healthier households are also wealthier ones. Is that simply because higher incomes lead to better health? Or does poor health restrict a family's ability to accumulate assets, because of its members' limited ability to work or through rising medical expenses?

Figure 3 indicates that the cross-sectional association between health and wealth is not trivial. This chart plots median wealth levels against self-reported health status in the sample of husband-wife families aged 70 and over. When either spouse is examined separately, those who are in excellent health have more than three times the wealth of those in poor health. Generally, each step down in health is associated with significantly lower wealth. This chart also demonstrates that the health of both spouses appear to be equally important. For example, if we compare households with both spouses in excellent health to those in which both spouses are in poor health, assets vary by a factor of almost ten to one. A decline in the health of either spouse is associated with lower levels of family wealth. 
But it is not only current health and current wealth that are related. Based on other results from the AHEAD survey, an improvement in health over a two-year period is also correlated with a higher level of initial household wealth. That is, households that start out with the highest wealth levels appear to have the least deterioration in health two years later. Finally, changes in wealth and changes in health also

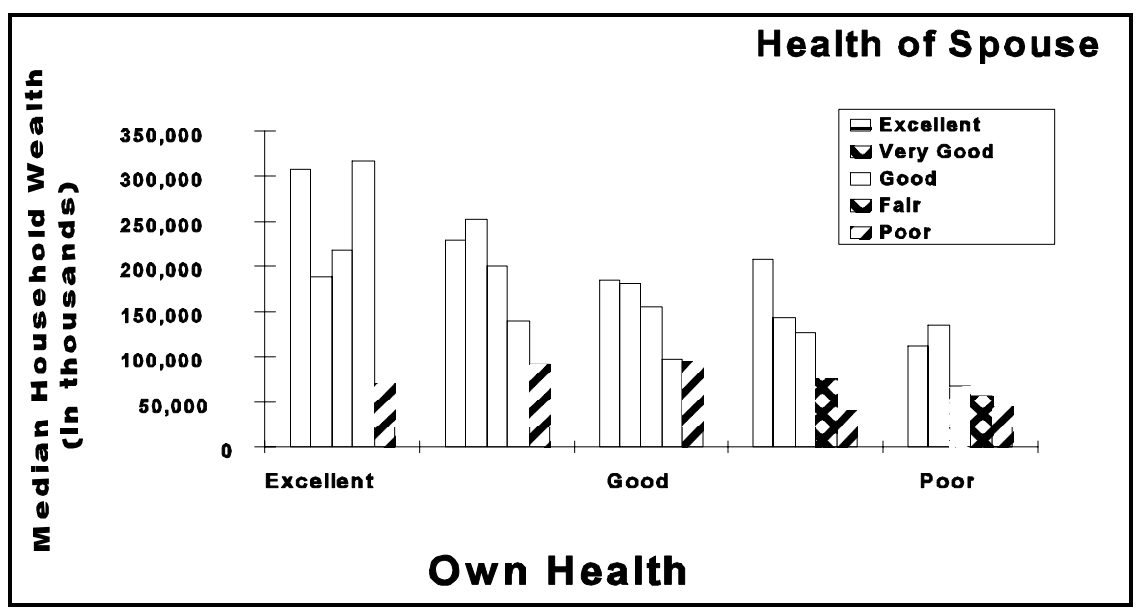

Figure 3. Household Wealth Depends on Health of Both Spouses. Source: AHEAD, calculations by author.

exhibit a strong association. Across a two-year period, assets grow fastest among households with improving health. Similarly, the slowest rate of wealth accumulation took place among those whose health was getting worse.

Does higher SES improve health or did good health increase income and wealth? To this point, nothing in these correlations proves what causes what. Both causal pathways are equally plausible a priori so theory alone can not show us the way. Economic resources may very well have a cumulative positive effect on health. Increased wealth or income can improve health and lengthen longevity for a number of reasons-greater access to medical care, reduced risk behaviors, and better nutrition to name a few. Extreme poverty, which is often associated with little sense of escape or hope, may lead to high levels of 


\section{Aging Studies Program Policy Brief}

stress that eventually may be manifested in disease and a set of chronic conditions.

Similarly, poor health could reduce income and wealth for a number of reasons. First, those in poor health are less able to work at all and, if they do work, they do so for fewer hours, resulting in lower income and consequently lower savings. These sick households also face higher medical expenses, which may deplete their past assets and further reduce their ability to save.

Well which is it? Are people healthier because they are wealthier or does good health promote wealth? In answering this question, we are definitely on the research frontier and our answers are necessarily more tentative.

But my recent research suggests that at ages 50 and over the dominant causation runs from health to economic status and not the other way around (see Smith and Kington 1997a, 1997b). After age 50, with the important exceptions of losing a job or a spouse, changes in a household's economic prospects are relatively modest. In contrast, changes in health can be large and can impact substantially on a household's economic circumstances. My research suggests that, at older ages, past and current health have strong impacts on household income and wealth, but changes in economic resources have little additional impact on health. The strong implication of this finding is that giving older people additional income or wealth at older ages will have little effect on their health status.

In light of my earlier dismissal of inheritances as an important factor in explaining current wealth disparities, it may now seem strange to argue that future bequests play a role in current wealth accumulations. The reason why these are not inconsistent positions is that there apparently exists a strong secular trend in inheritances (see Smith 1997). While people in their 50s have received relatively modest inheritances from their parents (and most in fact have received none), this pre-retirement generation currently plans on more substantial bequests to their children (and many more will do so). It remains the case, however, that 
the bequest motive for savings is an important empirical reality only among those in the top tier of the economic hierarchy.

Now, let's look at a third factor that may affect wealth accumulation of older people_-Social Security.

\# Household wealth ignores two critical components of wealth that can loom large, especially for households nearing and in retirement: pensions and Social Security.

Virtually, all of these pre-retirement households anticipate a flow of Social Security benefits when they retire. More than half of them are also counting on the income from their pensions. When discounted to the present, these expected income flows translate into considerable amounts of wealth. Combined, Social Security and pension wealth are as important as household wealth for the average family in their 50s (see Smith 1995 for more details on these points). Total wealth is almost half a million dollars instead of the roughly quarter of a million that we saw earlier.

This distortion caused by the conventional wealth concept is much larger among minority families. Among blacks and hispanics, conventional household wealth is less than a third of their total wealth. For minority households, Social Security wealth is especially critical and represents the largest part of their wealth, a subject to which I will soon return.

Not surprisingly, Social Security is particularly important among lowincome households. Among households that rank at the bottom ten percent in total "conventional" wealth, Social Security is the dominant, basically the only, form of wealth. Seventy percent of the wealth of these households rests in their future Social Security benefits. Very few of these pre-retirement households have any pensions in their past or their future.

While less extreme, Social Security wins first place in the wealth portfolio even for the median household. The average pre-retirement 


\section{Aging Studies Program Policy Brief}

white household has more Social Security wealth than either household wealth (including their home) or pensions. It is not even a close call for the typical black household, which has more wealth in Social Security than household and pension wealth combined.

These facts summarize the political and substantive power of Social Security: it is a highly successful redistributive system.

\section{The Need for Social Security Reform}

If Social Security is that successful in providing income security for the elderly, why do we have to change it? There are basically three reasons why reform is essential: the savings effect, some by now strange distribution impacts, and the looming fiscal imbalance resulting from the changing ratio between workers and retirees.

Table 4 illustrates our current Social Security system. This table lists expected income replacement rates from pensions and Social Security for pre-retirement households. These replacement rates represent the fraction of household income that will be replaced at the time they retire by pensions and Social Security. To illustrate with an example, the median household in this age group earns about $\$ 36,000$ per year. This table says that it will receive about $\$ 17,000$ in Social Security and pensions per year when they retire, which is 45 percent of their current annual income. 


\begin{tabular}{|c|c|c|c|}
\hline Table 4 & \multicolumn{3}{c|}{$\begin{array}{c}\text { Projected Income Replacement Rates during } \\
\text { Retirement (in percent) }\end{array}$} \\
\hline $\begin{array}{c}\text { Income } \\
\text { Percentile }\end{array}$ & Pension & $\begin{array}{c}\text { Social } \\
\text { Security }\end{array}$ & $\begin{array}{c}\text { Pension and Social } \\
\text { Security }\end{array}$ \\
\hline 5 & 10.8 & 81.6 & 92.4 \\
\hline 10 & 13.4 & 59.1 & 72.5 \\
\hline 20 & 16.7 & 42.1 & 58.8 \\
\hline 50 & 21.3 & 24.1 & 45.3 \\
\hline 80 & 21.8 & 15.4 & 37.3 \\
\hline 90 & 22.3 & 11.3 & 11.5 \\
\hline 95 & 19.6 & 9.4 & 29.0 \\
\hline Source: & $\begin{array}{c}\text { Health and Retirement Study (HRS), calculations } \\
\text { by author. }\end{array}$ \\
\hline \multicolumn{5}{|c}{} \\
\hline
\end{tabular}

The important news, however, is the sharply declining replacement rates with increasing income and the very high rates for low-income households. Over 90 percent of the current income of those at the bottom 5 percent will be replaced by pensions and Social Security, compared to only 29 percent of those at the top.

This table understates the actual extent of replacement since it does not take into account any of the income-conditioned safety net programs available to these households when they become older, such as SSI, food stamps, Medicare, and Medicaid. It is not an exaggeration to say that these low-income households may be better off when they retire than they are now. In that sense, current public policy has overannuitized our set of transfer programs since many of these preretirement households would prefer more money now at the expense of a little less in the future. Most important, the incentives these 


\section{Aging Studies Program Policy Brief}

households have to save for their own retirement is almost nil. This turns some of our earlier data somewhat on its head. One reason that low-income households have accumulated little private wealth of their own is that they have little incentive to do so.

Even if we did not have the oncoming fiscal crisis, Social Security is badly in need of reform. It is a program born of the Great Depression when there were double digit numbers of workers per retiree, life expectancy (or expected years spent in retirement) was much shorter, couples stayed married, and wives did not work. That clearly is not today's world.

To see how out of whack it often has become, consider some important results recently published by Panis and Lillard (1996). They provide some data on the distributional consequences of Social Security for the average cohort. Social Security is, after all, a transfer program that takes resources from some households and transfers them to other households. On average, then, the winners and losers must exactly offset each other. This central point is often ignored when one concentrates on the benefits received by past or current retirees, most of whom have done very well by the program. Their net benefit is, of course, a liability for future retirees who will of necessity receive less than they pay in.

Table 5 lists the difference between the present value of taxes paid compared to present value of benefits received for some important demographic subgroups. The distributional aspect of the current program is documented by the fact that high-income households lose income and low-income households gain income. However, this is by no means the only distributional consequence, and some of the other patterns are more troublesome. 
Table 5 Winners and Losers from the Social Security Program (present value of benefits - present value of taxes, in 1996 dollars)

\begin{tabular}{|c|c|c|c|}
\hline Unmarried & Benefit/Loss & Married & Benefit/Loss \\
\hline \multicolumn{2}{|l|}{ Men } & \multicolumn{2}{|c|}{ One-earner Couple } \\
\hline Low income & $\$-25,000$ & Low income & $\$+32,000$ \\
\hline Middle income & $-52,000$ & Middle income & $+60,000$ \\
\hline High income & $-72,000$ & High income & $+70,000$ \\
\hline \multicolumn{2}{|l|}{ Women } & \multicolumn{2}{|c|}{ Two-earner Couple } \\
\hline Low income & $+16,000$ & Low income & $-4,000$ \\
\hline Middle income & $+16,000$ & Middle income & $-9,000$ \\
\hline High income & $-15,000$ & High income & $-57,000$ \\
\hline
\end{tabular}

Unmarried men are among the big losers from Social Security largely because they have relatively low life expectancies and receive no spousal benefit. In a traditional single-income couple, the wife is entitled to a benefit equal to 50 percent of her spouse's benefit even though she made no payments into the program. Obviously, single individuals do not receive this payment. But two-earner couples also lose out because of this spousal benefit. Two-earner couples whose combined income equals that of the single-earner couple described above both pay money into the system, but they receive lower benefits than if the wife had paid nothing at all (Burkhauser and Smeeding 1994).

Who then are the big gainers from the current Social Security program? If the TV image of Ozzie and Harriet Nelson comes to mind, you are on the right track. Ozzie pays in and both Ozzie and Harriet receive checks. This type of redistribution may have made sense in 1936 and perhaps even in 1956, but it does not in 1997. In addition, as the 


\section{Aging Studies Program Policy Brief}

excellent work of researchers at the Center for Policy Research demonstrates, the program pays too much when both spouses are alive and too little to the surviving spouse, typically the wife (Burkhauser and Smeeding 1994).

The final reason for reform is the lack of budgetary balance, especially when combined with the rising health care costs for the elderly. Given our current pay-as-you-go financing system, basic demographics and economics require reform. As the baby boom generation ages and retires, the number of retirees will skyrocket relative to the working generations who must pay the bill.

Figure 4 illustrates the magnitude of these changes by plotting agespecific percentage changes in population sizes over the next half century. The smallest percent increase-about 4 percent—will take place among middle-age workers. These are the people who will be paying into the system. At the same time, the retired population will

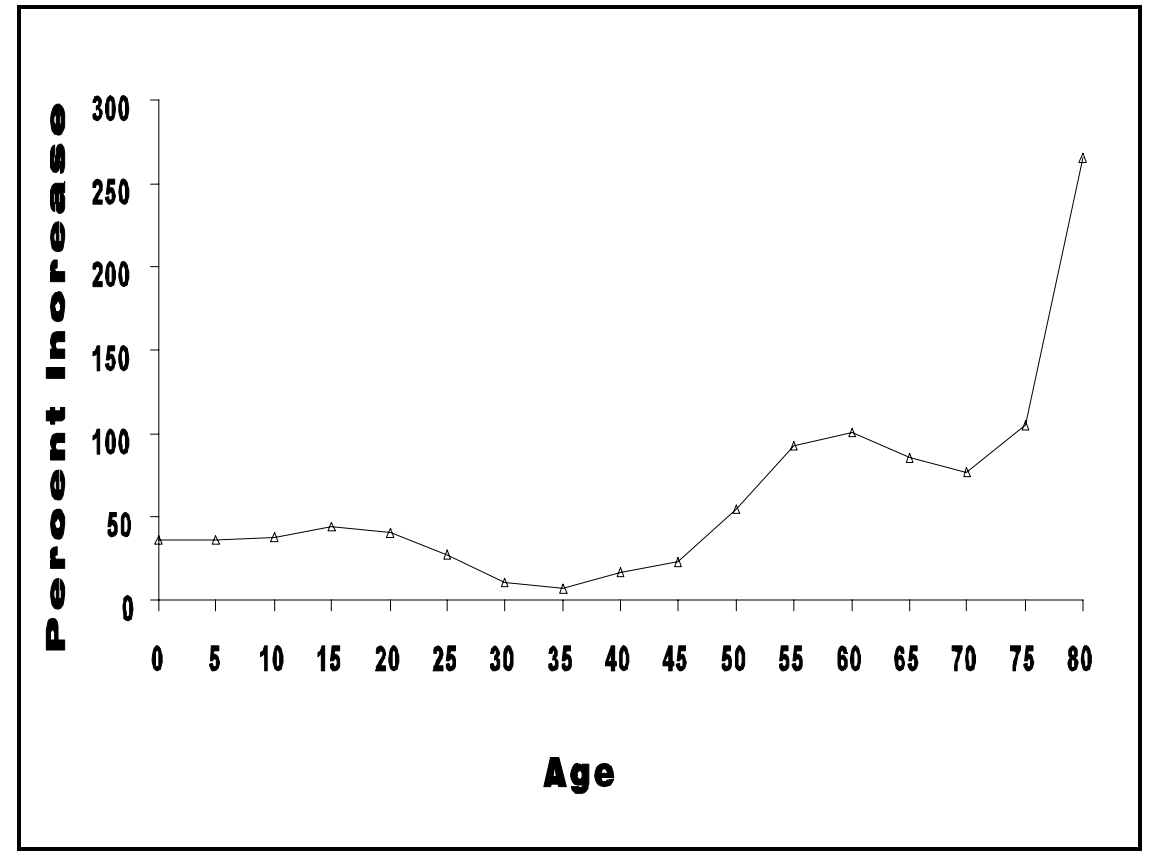

Figure 4. Projected Increases in the United States Population, 1995 to 2050, by Age. Source: Smith and Edmonston 1997. 
double and the number of those aged 80 or more will more than triple. This latter increase is especially daunting since health care costs are concentrated the oldest-old. While we will have about a million and a half more workers aged 36-40 in the year 2050, there will be about eight and one half million more retirees aged 66-70. If that doesn't get your attention, think about the more than twenty million additional people over age 80.

The second reason underlying budgetary imbalance is economic. Today, federal government outlays on Social Security, Medicare, and Medicaid combined are about 8 percent, measured as a fraction of Gross National Product (GNP). If our current benefit system for health care and Social Security is maintained, this fraction will rise to at least 20 percent by the middle of the next century. This fraction is about equal to the current size of the federal budget. At the same time, interest on the public debt will rise to 16 percent of GNP from the current 3 percent. This clearly represents an unsustainable level.

There is no question about whether or not to cut age-related entitlements. They must be cut, and eventually they will be cut. The real public policy question is how to trim age-related entitlements to protect the truly needy (which is not synonymous with the current elderly) and when to cut them so that people will have time to adjust.

Putting aside all the camouflage, in our pay-as-you-go system, current workers pay for the retirement benefits of current retirees. The following equations summarizes the long-run fiscal balancing equation in our Social Security system, in which revenue must equal expenditures. Revenue is generated by the number of workers $(\mathrm{N})$ multiplied by the average wage $(\mathrm{W})$ and the average payroll tax $(\mathrm{t})$. Expenditures are equal to the number of retirees $(\mathrm{R})$ times the average benefit per retiree (B). Rearranging terms, we can compute the payroll tax that makes the system solvent.

$$
\mathrm{t}=(\mathrm{B} / \mathrm{W}) *(\mathrm{R} / \mathrm{N})
$$




\section{Aging Studies Program Policy Brief}

The two critical parameters determining the tax rate are the replacement rate (B/W in this formula) and the number of retirees per worker $(\mathrm{R} / \mathrm{N})$. Our current average replacement rate is 40 percent. If we had 12 workers for every retiree, the payroll tax would have to be less than 4 percent. That's about what we had when the system started, and the fiscal burden was low. At three and one half workers per retiree, the payroll tax rises to 12 percent (that's where we are now). If we end up with two workers for every retiree (pretty much where we are headed), the payroll tax will have to rise to 20 percent.

\section{What are the Policy Options for Reform?}

Reduce benefits, increase taxes, change the dependency ratio, or promote economic growth. Sounds simple enough, doesn't it? But there will be some big winners and losers, depending on which path we take, and the battle lines are already drawn. To have a solvent system by the middle of the next century implies either a 30 percent reduction in benefits or a 5 percent increase in payroll taxes. Who wins and who loses from each option may not be as obvious as you think.

There are four frequently mentioned policy options - cutting other government expenditures, raising the payroll tax, reducing benefits, and increasing the retirement age. Placing Social Security off limits and cutting other government programs has basically been our political compromise for the last decade. To achieve long-term balance, this solution is neither realistic or equitable. It is not realistic given the size of the cuts required. If Medicaid is also left alone, these reductions would come close to completely wiping out all non-defense non-age related government programs. What is the equity in drastically cutting programs that serve low-income families while keeping completely intact a program such as Social Security where many of the benefits go to the comfortable or the well-to-do?

Within the Social Security program, then, structural changes will have to be made. In light of the heavy dependance of poor elderly people on Social Security documented above, the changes made should be progressive. But different cohorts bear the burden of reform, depending 
on whether we raise taxes, cut benefits, or increase the retirement age, and these impacts tend to be ignored when selecting policy options.

It should come as no surprise that current retirees prefer payroll tax increases or increases in the retirement age, the impact of which totally escape them. Even current workers in their 40s or 50 s prefer a tax increase to a benefit reduction. Their taxpaying years are half over, but their benefit years lie fully before them.

Those who adhere religiously to not changing the current benefit formula, and who cite equity as the reason, should be required to answer one question: What is the equity in imposing large penalties on low- and middle-income people in younger cohorts, while leaving current middle and well-to-do retirees alone?

\# Gradual benefit reduction should be a central component of reform. These reductions in benefits should begin now. In that way, all cohorts will share in the cost of reform and the reduction required of any single group is manageable.

However, reform of age-related entitlements in isolation is not a full public policy response. Private pension prevalence rates have already started to decline among younger households, reversing almost a century old trend. And our current Social Security promises are impossible to keep in the future. We know it, and younger generations know it. Two legs of the retirement stool are guaranteed to fall.

What about the remaining leg, private savings? Here, the early evidence is not promising. The baby-boom generations are apparently actually saving at lower rates than their predecessors (see Juster, Smith, and Stafford 1997).

What can be done? At one level, the overwhelming dimensions of the problem makes the outline of the solution clear, although we all know how politically difficult it will be to implement. For openers, we have to start making realistic promises about our public tier and focus only on ensuring a decent standard of living for the poor old. Our long-run 


\section{Aging Studies Program Policy Brief}

policy goal should be to start turning our public component of the retirement stool into a sustainable system with the twin but limited goals of reducing old age poverty and coinsuring against some multiple risks, including health. We can accomplish this through a means-tested benefit, or a universal flat benefit, but accomplish it we must.

With the inevitable decline in our dependence on the pay-as-you-go public tier, we must strengthen the private sector tier though additional private savings. Given the daunting dimensions of our future problems, we must be bold. Here, too, there are legitimate disagreements about the direction to go, but the boldness requirement pushes us toward a progressive consumption tax to voluntarily encourage savings, or a mandatory provident type fund that deducts a certain percent of income for future retirement.

Given how ingrained our poor savings habits appear to be nowadays, we may also have to go beyond traditional methods of providing individuals incentives to save: perhaps we need a publicly-funded information campaign to promote the value of savings. That campaign should stress over and over again the two key strategies for successful wealth accumulation—start young and stay the course. 
James P. Smith

\section{References}

Burkhauser, Richard V. and Timothy M. Smeeding. 1994. Social Security Reform: A Budget Neutral Approach to Reducing Older Women's Disproportionate Risk of Poverty. Center for Policy Research Policy Brief No. 2/1994. Syracuse, NY: Syracuse University.

Deaton, Angus 1992. Understanding Consumption. Oxford, UK: Clarenton Press.

Hubbard, R. Glenn, Jonathan Skinner, and Steven Zeldes. 1995. "Precautionary Savings and Social Insurance," Journal of Political Economy, No 2, Vol 103 (April), pp 360-399.

Juster, F. Thomas, James P. Smith, and Frank Stafford. 1997. "Savings and Wealth, and Income: Then and Now." Paper presented at the Conference on Health and Retirement, Amsterdam, The Netherlands.

Panis, Constantijn W.A. and Lee A. Lillard 1996. "Social Security: Equity, Adequacy, Reforms.” Document No. DB-167-NIA, Santa Monica, CA: RAND.

Smith, James P. 1995. "Racial and Ethnic Differences in Wealth," Journal of Human Resources, Vol.XXX, pp. S158-S183.

Smith, James P. 1997. "Wealth Inequality Among Older Americans," Journal of Gerontology, Vol 52B ( May), pp. 74-81.

Smith, James P. and Barry Edmonston, Panel on the Demographic and Economic Impacts of Immigration, National Research Council, editors, 1997, The New Americans: Economic, Demographic, and Fiscal Effects of Immigration, Washington, DC: National Academy Press. 
Aging Studies Program Policy Brief

Smith, James P. 1997. “Bequests and Inheritances.” In James P. Smith and Robert Willis, editors, Essays in Honor of F. Thomas Juster, Ann Arbor: University of Michigan Press, forthcoming.

Smith, James P. and Raynard S. Kington. 1997. "Demographic and Economic Correlates of Health in Old Age," Demography. Vol 34. No. 1 ( February), pp 159-170.

Smith, James P. and Raynard S. Kington. 1997 "Race, Socioeconomic Status, and Health in Late Life." In Linda G. Martin and Beth J. Soldo, Committee on Population, National Research Council, editors, Racial and Ethnic Differences in the Health of Older Americans, Washington, DC: National Academy Press.

U.S. Bureau of the Census, 1991. Poverty in the United States: 1990, Current Population Reports, Series P-60, No. 175, Tables 2-3, Washington, DC: U.S. Government Printing Office. 